\title{
Mycetocola reblochoni sp. nov., isolated from the surface microbial flora of Reblochon cheese
}

\section{Correspondence \\ Michael Goodfellow \\ m.goodfellow@ncl.ac.uk}

\author{
Nagamani Bora, ${ }^{1}$ Marc Vancanneyt, ${ }^{2}$ Roberto Gelsomino, ${ }^{2}$ \\ Cindy Snauwaert, ${ }^{2}$ Jean Swings, ${ }^{2,3}$ Amanda L. Jones, ${ }^{1}$ Alan C. Ward, ${ }^{1}$ \\ Jean-Francois Chamba, ${ }^{4}$ Reiner M. Kroppenstedt, ${ }^{5}$ Peter Schumann ${ }^{5}$ \\ and Michael Goodfellow ${ }^{1}$
}

\author{
${ }^{1}$ School of Biology, Ridley Building, Newcastle University, Newcastle upon Tyne NE1 7RU, UK \\ ${ }^{2}$ BCCM/LMG Bacteria Collection, Faculteit Wetenschappen, Ghent University, B-9000 Ghent, \\ Belgium \\ ${ }^{3}$ Laboratorium voor Microbiologie, Faculteit Wetenschappen, Ghent University, B-9000 Ghent, \\ Belgium \\ ${ }^{4}$ Institut Technique Français des Fromages, 419, Route des Champs Laities, BP30, $74801 \mathrm{La}$ \\ Roche sur Foron Cedex, France \\ ${ }^{5} \mathrm{DSMZ}$ - German Collection of Microorganisms and Cell Cultures, Braunschweig, Germany
}

The largely undefined microbial communities present on the surfaces of smear-ripened cheeses (Eliskases-Lechner \& Ginzinger, 1995; Valdes-Stauber et al., 1997) include members of novel bacterial taxa. Corynebacterium casei and Microbacterium gubbeenense, for instance, were isolated from the surface of the Irish farmhouse surface-ripened cheese Gubbeen (Brennan et al., 2001a, b, 2002), and Arthrobacter bergerei and Arthrobacter arilaitensis were isolated from different smear-ripened cheeses (Irlinger et al., 2005). During the course of a study into the biodiversity of the surface flora of Reblochon cheese, a traditional smear-ripened cheese manufactured from cow's milk in a restricted area of the northern French Alps, a homogeneous group of coryneform strains were isolated and provisionally assigned to the family Microbacteriaceae Park et al. 1995 emend. Rainey et al. 1997 (Park et al., 1993; Stackebrandt et al., 1997). Representative

The GenBank/EMBL/DDBJ accession numbers for the 16S rRNA gene sequences of strains LMG 22367 ${ }^{\top}$, LMG 23021, LMG 23022 and LMG 23020 are DQ062097-D0062100, respectively. members of this group plus the type strains of recognized Mycetocola species were the subject of a polyphasic taxonomic study, which showed that the Reblochon strains represent a novel species of the genus Mycetocola.

At the time of writing, the family Microbacteriaceae comprises 21 genera with validly published names, including the recently described genera Frondicola and Labedella (Lee, 2007). The family includes coccoid, rod-shaped and mycelium-forming strains that have a $\beta$-type cell-wall peptidoglycan and unsaturated menaquinones. The constituent genera can be distinguished readily based on chemotaxonomic characteristics, such as the diamino acid of the cell-wall peptidoglycan ( $\gamma$-aminobutyric acid, 2,4-diaminobutyric acid, lysine and ornithine) and fatty acid, menaquinone and polar lipid components (Evtushenko \& Takeuchi, 2006; Sheridan et al., 2003; Manaia et al., 2004; Lee, 2007).

Bacteria were isolated from Reblochon cheese following suspension and homogenization (stomacher; Interscience) of samples of the red smear surface in sodium citrate $(2 \%$, 
w/v). After tenfold dilutions and plating onto plate count agar (PCA; Biokar Diagnostic) supplemented with 3\% $(\mathrm{w} / \mathrm{v})$ sodium chloride, cultures were isolated, purified and screened by using rep-PCR. They were then grown for $1-2$ days at $30{ }^{\circ} \mathrm{C}$ on trypticase soy broth (TSB; Difco) containing $1.5 \%$ agar (Oxoid). DNA isolation and electrophoresis were performed according to Gevers et al. (2001) and PCR was performed with the primer BOXA1R following Versalovic et al. (1994). Band patterns were analysed by using Pearson's product-moment correlation coefficient and UPGMA cluster analysis with Bionumerics software (Applied Maths), and were then compared with a database consisting of type and representative strains of the most common species present on red smear cheeses (data not shown). A homogeneous cluster consisting of eight isolates (LMG 22367 ${ }^{\mathrm{T}}$, LMG 23020, LMG 23021, LMG 23022, R-20391, R-20398, R-20413 and R-20423) remained unidentified; the taxonomic position of these isolates is the subject of the present study.

The eight strains were isolated from Reblochon cheeses manufactured in September 2002 in three different farmhouses. The cheeses were made from raw milk without the addition of starter surface microflora and were ripened on wooden shelves. All of the isolates were recovered at the late stage of ripening, i.e. after about 15 days. Four representative strains, LMG $22367^{\mathrm{T}}$, LMG 23020, LMG 23021 and LMG 23022, were selected for further taxonomic study. The reference type strains used in the present study, Mycetocola lacteus LMG $22187^{\mathrm{T}}$, Mycetocola saprophilus LMG $22188^{\mathrm{T}}$ and Mycetocola tolaasinivorans LMG $22189^{\mathrm{T}}$, were obtained from the BCCM/LMG Bacteria Collection (http://www.belspo.be/bccm/lmg.htm).

The phylogenetic position of the representative isolates was determined by $16 \mathrm{~S}$ rRNA gene sequence analysis. Cells of the organisms were grown in brain heart infusion broth (Difco) for 5 days at $30{ }^{\circ} \mathrm{C}$, and the biomass was checked for purity, harvested by centrifugation, washed in $\mathrm{NaCl} /$ EDTA buffer (0.1 M EDTA, $0.1 \mathrm{M} \mathrm{NaCl}, \mathrm{pH} 8.0)$ and stored at $-20{ }^{\circ} \mathrm{C}$ until required. Genomic DNA, extracted as described by Sambrook \& Russell (2001), was used as template for PCR amplification and sequencing following the procedure of Kim et al. (1998). The resultant almostcomplete $16 \mathrm{~S}$ rRNA gene sequences (1541 nt) were aligned manually with corresponding sequences of representatives of the genera classified in the family Microbacteriaceae, retrieved from the RDP and GenBank databases, by using the pairwise alignment option and 16S rRNA secondary structure information held in the PHYDIT program (available at http://plaza.snu.ac.kr/ jchun/phydit/).

Phylogenetic trees were inferred by using the least-squares (Fitch \& Margoliash, 1967), maximum-parsimony (Kluge \& Farris, 1969) and neighbour-joining (Saitou \& Nei, 1987) tree-making algorithms from the PHYDIT program. Evolutionary distance matrices for the least-squares and neighbour-joining algorithms were generated by using the distance model of Jukes \& Cantor (1969). The resultant unrooted tree topologies were evaluated in a bootstrap analysis (Felsenstein, 1985) of the neighbour-joining dataset by using the SEQBOOT and CONSENSE options from the PHYLIP package (Felsenstein, 1993). The resultant phylogenetic analyses showed that the new isolates formed an independent phyletic line among the actinomycete genera classified in the family Microbacteriaceae (Stackebrandt et al., 1997; Lee, 2007) (Fig. 1). The new isolates shared $16 \mathrm{~S}$ rRNA gene sequence similarities of $99.9-100 \%$ and were most closely related to the type strains of Mycetocola species, namely Mycetocola lacteus LMG $22187^{\mathrm{T}}$, Mycetocola saprophilus LMG $22188^{\mathrm{T}}$ and Mycetocola tolaasinivorans LMG $22189^{\mathrm{T}}$. The relationship between the new isolates and the Mycetocola strains was supported by all of the tree-making algorithms and by a high level ( $80 \%)$ of bootstrap support in the neighbour-joining analysis. Mycetocola strains were not included in the initial rep-PCR screening as members of this taxon have not been found previously amongst the surface flora of red smear cheeses.

SDS-PAGE of whole-organism proteins, a method routinely used for species delineation, was carried out as a screening method to reveal relationships between the representative isolates and the Mycetocola reference strains. Mycetocola lacteus LMG $22187^{\mathrm{T}}$, Mycetocola saprophilus LMG $22188^{\mathrm{T}}$ and Mycetocola tolaasinivorans LMG $22189^{\mathrm{T}}$ and the Reblochon isolates were cultivated as indicated for the repPCR analyses. Whole-organism protein extracts were prepared and SDS-PAGE was performed as described by Pot et al. (1994). Densitometric analysis, normalization and interpolation of protein profiles, and numerical analyses were carried out by using Gelcompar software package, versions 3.1 and 4.0 (Applied Maths). The Reblochon isolates formed a homogeneous cluster that was sharply separated from the Mycetocola reference strains (Fig. 2).

The DNA G+C content of strain LMG $22367^{\mathrm{T}}$ was determined. Cells were cultivated in TSB for $24 \mathrm{~h}$ at $28{ }^{\circ} \mathrm{C}$. DNA was extracted from $0.75-1.25 \mathrm{~g}$ wet weight of cells by using the protocol described by Pitcher et al. (1989) with the following modifications: the washed cell pellet was resuspended and lysed in a buffer $(10 \mathrm{mM}$ Tris/ $\mathrm{HCl}$, $100 \mathrm{mM}$ EDTA, pH 8.0) containing RNase $\left(200 \mu \mathrm{g} \mathrm{ml}^{-1}\right.$; Sigma), mutanolysin (100 $\mathrm{U} \mathrm{ml}^{-1}$; Sigma) and lysozyme (25 mg ml${ }^{-1}$; SERVA) for $1 \mathrm{~h}$ at $37^{\circ} \mathrm{C}$. Before the addition of GES reagent, proteinase $\mathrm{K}\left(200 \mu \mathrm{g} \mathrm{ml}^{-1}\right.$; Merck) was added to the mixture for $15 \mathrm{~min}$ and the DNA was degraded enzymically into nucleosides, as described by Mesbah et al. (1989). The nucleoside mixture was separated by HPLC by using a Waters SymmetryShield C8 column maintained at $37{ }^{\circ} \mathrm{C}$ with $0.02 \mathrm{M} \mathrm{NH}_{4} \mathrm{H}_{2} \mathrm{PO}_{4}(\mathrm{pH} 4.0)$ and $1.5 \%$ acetonitrile as the solvent. Non-methylated $\lambda$-phage DNA (Sigma) was used as the calibration reference. The DNA G + C content of strain LMG $22367^{\mathrm{T}}$ was $70 \mathrm{~mol} \%$, a value higher than the $64-65 \mathrm{~mol} \%$ reported for recognized members of the genus Mycetocola (Tsukamoto et al., 2001).

DNA-DNA hybridizations were performed between strain LMG $22367^{\mathrm{T}}$ and Mycetocola lacteus LMG $22187^{\mathrm{T}}$, 


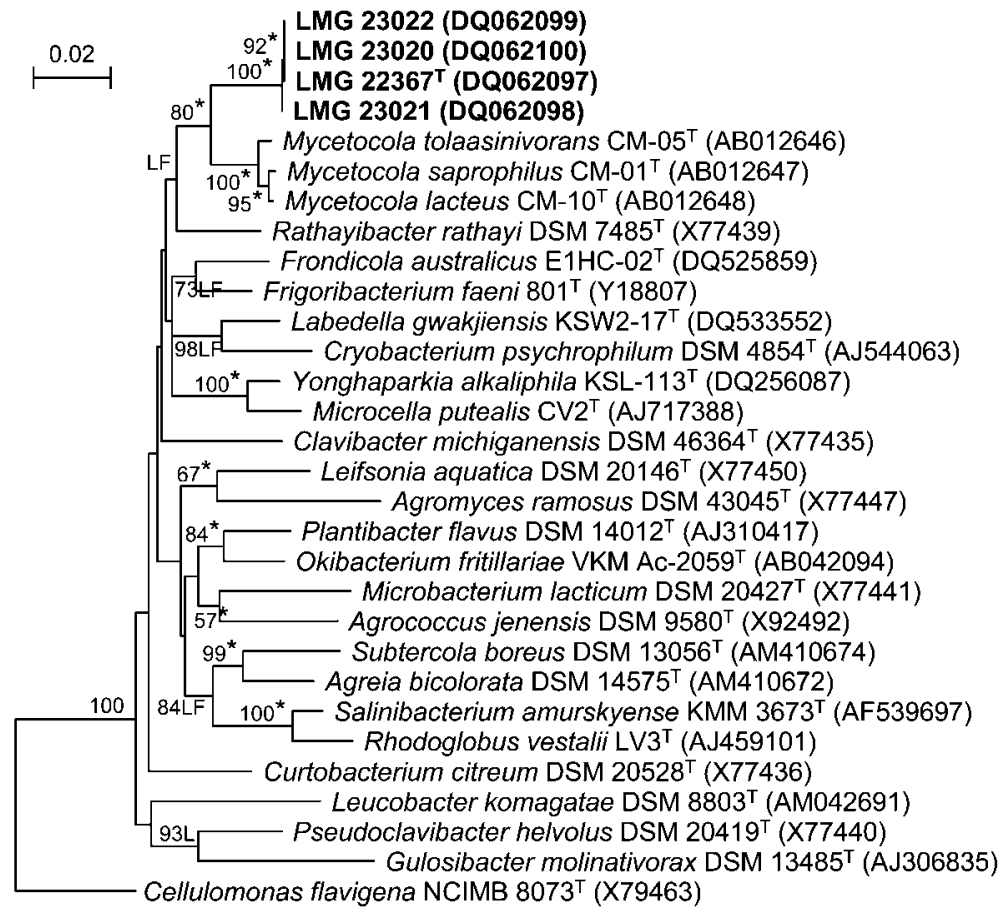

Fig. 1. Neighbour-joining tree (Saitou \& Nei, 1987) based on nearly complete $16 \mathrm{~S}$ rRNA gene sequences showing the position of isolates LMG $22367^{\top}$, LMG 23020, LMG 23021 and LMG 23022 in the Microbacteriaceae 16S rRNA gene tree. Asterisks indicate branches of the tree that were also found by using the least-squares (Fitch \& Margoliash, 1967), maximum-likelihood (Felsenstein, 1993) and maximum-parsimony (Kluge \& Farris, 1969) tree-making algorithms. $\mathrm{L}$ and $\mathrm{F}$ respectively indicate branches that were recovered by using the maximum-likelihood and leastsquares methods. Numbers at nodes indicate levels of bootstrap support based on a neighbour-joining analysis of 1000 resampled datasets; only values above $50 \%$ are given. Bar, 0.02 substitutions per nucleotide position.

Mycetocola saprophilus LMG $22188^{\mathrm{T}}$ and Mycetocola tolaasinivorans LMG $22189^{\mathrm{T}}$ by using genomic DNA prepared according to the protocol described above. The microplate method was employed as described by Ezaki et al. (1989) and Goris et al. (1998), by using an HTS7000 Bio Assay Reader (Perkin Elmer) for the fluorescence measurements. Biotinylated DNA was hybridized with unlabelled singlestranded DNA which was bound non-covalently to microplate wells. Hybridizations were performed at $50{ }^{\circ} \mathrm{C}$ in a hybridization mixture $(2 \times$ SSC, $5 \times$ Denhardt's solution, $2.5 \%$ dextran sulfate, $50 \%$ formamide, $100 \mu \mathrm{g}$ denatured salmon sperm DNA $\mathrm{ml}^{-1}, 1250 \mathrm{ng}$ biotinylated probe DNA $\mathrm{ml}^{-1}$ ). Levels of DNA-DNA relatedness were calculated as means based on at least two independent hybridization experiments; reciprocal reactions were performed and considered as independent hybridization experiments. Levels of DNA-DNA relatedness of 6-8\% were found between strain LMG $22367^{\mathrm{T}}$ and the type strains of recognized Mycetocola species, suggesting that the Reblochon isolates represent a novel species.

Peptidoglycan analyses were carried out to establish whether strains LMG $22367^{\mathrm{T}}$, LMG 23020, LMG 23021 and LMG 23022 represented a novel Mycetocola species or a new genus in the family Microbacteriaceae. Towards this end, the three isolates and the type strains of the three recognized Mycetocola species were grown in brain heart infusion broth (Difco) for 5 days at $28^{\circ} \mathrm{C}$, and the resultant biomass was washed twice in distilled water and freeze-dried. Purified peptidoglycan preparations were obtained after disruption of cells by shaking with glass beads and subsequent trypsin digestion, according to the method of Schleifer (1985). The amino acids and peptides in the cell-wall hydrolysates were analysed by twodimensional ascending TLC on cellulose plates by using the solvent systems described by Schleifer (1985). The Nterminal amino acids of the interpeptide bridges were detected by dinitrophenylation, as described by Schleifer (1985). The molar ratios of the amino acids were determined by GC and GC-MS of $N$-heptafluorobutyryl amino acid isobutyl esters (MacKenzie, 1987; Groth et al., 1996). A standard procedure was also used to determine the muramic acid type (Uchida et al., 1999).

Cell-wall hydrolysates of the novel strains contained major amounts of lysine as the diagnostic cell-wall diamino acid; the molar ratios of lysine, alanine, glycine and glutamic acid were estimated to be $1.0: 0.7: 1.1: 1.8$ for strain LMG 23020, $1.0: 0.6: 1.1: 1.6$ for strain LMG $22367^{\mathrm{T}}, 1.0: 6.8$ : $1.6: 2.0$ for strain LMG 23021, $1.0: 0.6: 1.0: 1.6$ for Mycetocola lacteus DSM $15177^{\mathrm{T}}$, 1.0:0.5:0.8:1.7 for Mycetocola saprophilus DSM $15178^{\mathrm{T}}$ and $1.0: 0.7: 1.0: 1.7$ for Mycetocola tolaasinivorans DSM $15179^{\mathrm{T}}$; the unusually high alanine content found for strain LMG 23021 might be due to contaminating protein. The peptidoglycan preparations of the Mycetocola type strains, like those of the new isolates (except strain LMG 23021), had a low alanine content, and more than one glutamic acid residue per lysine residue. Alanine occurred as the N-terminal amino acid of the interpeptide bridge in Mycetocola saprophilus DSM $15178^{\mathrm{T}}$, Mycetocola tolaasinivorans DSM $15179^{\mathrm{T}}$ and strains LMG $22367^{\mathrm{T}}$, LMG 23020 and LMG 23021. The peptide patterns of the partially hydrolysed peptidoglycan of all of the novel strains were very similar, consisting of the dipeptides L-AlaD-Glu, Gly-D-Glu and L-Lys-D-Ala; these data justify the conclusion that these strains have a $\beta$-type peptidoglycan 


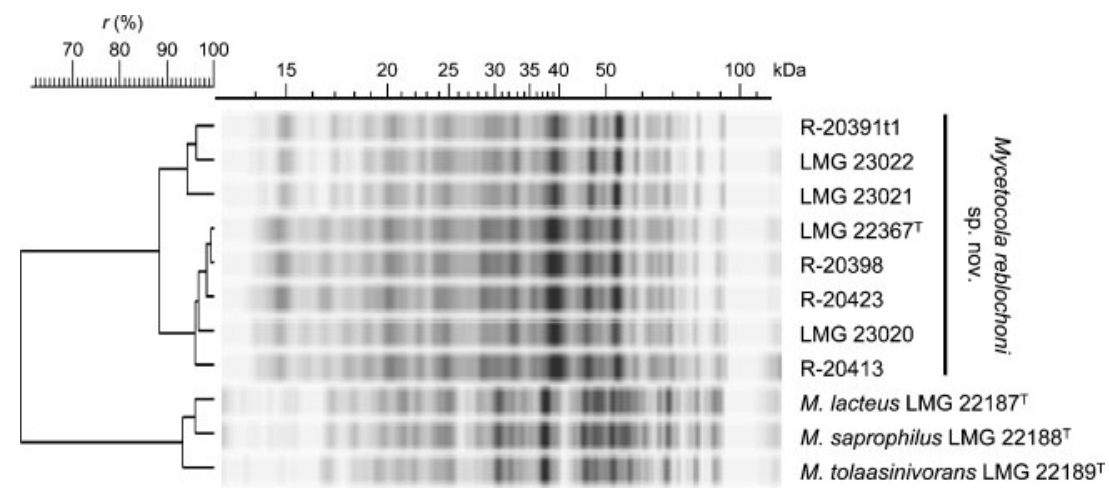

\begin{abstract}
Fig. 2. SDS-PAGE protein patterns of the new isolates and the type strains of recognized Mycetocola species. The dendrogram was generated by UPGMA linkage of correlation coefficients ( $r$, expressed for convenience as percentage similarity).
\end{abstract}

(Schleifer, 1985), a finding that is in line with the phylogenetic positions of the organisms. It is evident from these results that the peptidoglycan structure of the new isolates and of the type strains of the Mycetocola strains are very similar. Indeed, the peptidoglycan data differ from those of all known peptidoglycans based on lysine (http://www. dsmz.de/microorganisms/main.php?content_id=35). All of the new isolates contained $\mathrm{N}$-acetylated muramic acid.

Strain LMG $22367^{\mathrm{T}}$ and the type strains of the Mycetocola species were examined for additional chemotaxonomic markers. Polar lipids and isoprenoid quinones were extracted from freeze-dried biomass following the procedure described by Minnikin et al. (1984). The polar lipids were separated by using a standard TLC technique (Minnikin et al., 1984) and the isoprenoid quinone extracts were filtered and reduced to dryness in a stream of nitrogen. The resultant dried preparations were dissolved in $200 \mu \mathrm{l}$ propanol and filtered by using a Dyna Gard $0.2-\mu \mathrm{l}$ syringe filter and $5 \mu \mathrm{l}$ of the filtered extract was separated by HPLC following Kroppenstedt (1985). Fatty acid methyl esters were prepared and analysed following Klatte et al. (1994) by using the standard Microbial Identification System (MIDI system; http://www.midi-inc.com/).

All of the organisms gave a simple polar lipid pattern that consisted of two phospholipids, a major diphosphatidylglycerol spot, a faint phosphatidylglycerol spot and a prominent glycolipid that was visualized by spraying with anisaldehyde. All of the strains contained unsaturated menaquinones with ten isoprene units as the predominant isoprenologue, although strain LMG $22367^{\mathrm{T}}$ produced smaller proportions of MK-9 and MK-11 compared with the other strains and lacked MK-8 (Table 1). It can be seen from this table that the strains also shared similar fatty acid profiles, with 12-methyl tetradecanoic acid as the major component, although all four strains could be separated based on quantitative differences in major fatty acid components.

The presence of lysine in the cell-wall peptidoglycan of the new isolates readily distinguished them from genera of the family Microbacteriaceae that contain other cell-wall diamino acids (Zhang et al., 2007). Additional chemical markers could be used to distinguish the new isolates from genera in the family that contain lysine in the peptidoglycan. Thus, strain
Table 1. Fatty acid and menaquinone profiles (\%) of strain LMG $22367^{\top}$ and the type strains of recognized Mycetocola species

Strains: 1, LMG 22367 $; 2$, Mycetocola lacteus DSM $15177^{\mathrm{T}}$; 3, Mycetocola saprophilus DSM $15178^{\mathrm{T}}$; 4, Mycetocola tolaasinivorans DSM $15179^{\mathrm{T}} .-$, Not detected. Abbreviations are exemplified by the following: anteiso-15:0, 12-methyl tetradecanoic acid; 16:0, hexadecanoic acid; iso-16:0, 14-methyl pentadecanoic acid.

\begin{tabular}{|lcccc|}
\hline Component & $\mathbf{1}$ & $\mathbf{2}$ & $\mathbf{3}$ & \multicolumn{1}{c|}{$\mathbf{~}$} \\
\hline Fatty acids & & & & \\
anteiso-13:0 & - & - & - & 0.09 \\
iso-14:0 & 0.42 & 0.56 & 0.59 & 0.83 \\
$14: 0$ & - & 0.81 & 0.85 & 2.14 \\
anteiso-15: & 0.92 & - & - & - \\
iso-15 & 0.74 & 1.90 & 2.03 & 0.77 \\
anteiso-15:0 & 44.48 & 47.88 & 48.71 & 50.31 \\
$15: 0$ & - & 1.02 & 1.09 & 2.07 \\
iso-16:0 & 10.23 & 11.2 & 11.18 & 9.73 \\
$16: 0$ & 14.26 & 17.23 & 17.65 & 20.31 \\
iso-17:0 & 0.51 & 0.95 & 0.90 & 0.22 \\
anteiso-17:0 & 28.44 & 17.61 & 16.29 & 12.76 \\
$17: 0$ & - & 0.48 & 0.46 & 0.52 \\
$18: 0$ & - & 0.31 & 0.25 & 0.25 \\
Menaquinones & & & & \\
MK-8 & - & 7.4 & 7.2 & 9.8 \\
MK-9 & 2.0 & 30.7 & 30.4 & 30.9 \\
MK-10 & 95.0 & 53.2 & 53.3 & 50.8 \\
MK-11 & 3.0 & 8.7 & 9.1 & 8.5 \\
& & & & \\
\hline
\end{tabular}

LMG $22367^{\mathrm{T}}$ could be distinguished from Frigoribacterium and Microcella strains based on its major fatty acid and menaquinone components (Kämpfer et al., 2000; Tiago et al., 2005), and strains LMG $22367^{\mathrm{T}}$, LMG 23020 and LMG 23022 could be distinguished from members of the genera Microbacterium and Okibacterium as the former contain $\mathrm{N}$ acetylated muramic acid and the latter $\mathrm{N}$-glycolated muramic acid (Takeuchi \& Hatano, 1998; Evtushenko et al., 2002). By contrast, strain LMG $22367^{\mathrm{T}}$ and the type strains of Mycetocola lacteus, Mycetocola saprophilus and Mycetocola tolaasinivorans showed very similar chemotaxonomic profiles based on the present as well as previous data (Tsukamoto et al., 2001). 
Table 2. Differential characteristics between strain LMG $22367^{\top}$ and the type strains of recognized Mycetocola species

Strains: 1, LMG $22367^{\mathrm{T}}$ (identical results were obtained for strains LMG 23020, LMG 23021 and LMG 23022); 2, Mycetocola lacteus LMG $22187^{\mathrm{T}}$; 3, Mycetocola saprophilus LMG $22188^{\mathrm{T}}$; 4, Mycetocola tolaasinivorans LMG $22189^{\mathrm{T}}$. All strains were positive for aesculin and arbutin hydrolysis, produced acid from cellobiose, fructose, glucose, glycerol, maltose, mannitol and ribose, utilized adonitol, amygdalin, L-arabinose, D-arabinose, arbutin, cellobiose, dextrin, dulcitol, i-erythritol, ethanol, D-fucose, L-fucose, fructose, galactose, glucose, glycerol, glycogen, myo-inositol, inulin, lactose, maltotriose, mannitol, mannose, melezitose, melibiose, methyl $\alpha$-D-glucoside, raffinose, $\alpha$-L-rhamnose, ribose, salicin, sorbitol, sorbose, starch, sucrose, trehalose, turanose, xylitol and xylose as sole carbon sources, degraded tributyrin and Tween 40, utilized butan-1,3-diol, butan-1,4diol, butan-1-ol, butan-2,3-diol, isoamyl alcohol and propan-1,2-diol (all at $1 \%, \mathrm{v} / \mathrm{v}$ ), sodium acetate, adipate, butyrate, citrate, fumarate, gluconate, lactate, mandelate, malate, pyruvate, propionate, sebacate, succinate and valerate (at $0.1 \%, \mathrm{w} / \mathrm{v}$ ) as sole carbon sources and Laspartic acid, L-ornithine and thymidine as sole carbon and nitrogen sources and produced esterase lipase (C8) and naphthol-AS-B1 phosphohydrolase. None of the strains degraded elastin, gelatin, guanine, hypoxanthine, uric acid, xanthine or xylan, hydrolysed allantoin, utilized $m$-hydroxybenzoic acid, $p$-hydroxybenzoic acid, hydroxybutyric acid, malonate, oleate or oxalate as sole carbon sources or acetamide, L-alanine, L-aminobutyric acid, L-arginine, Lcysteine, L-glutamic acid, L-glycine, L-isoleucine, L-norleucine, DLmethionine, monoethanolamine, DL-norleucine, L-norvaline, L-phenylalanine, L-proline, L-serine, L-threonine, L-tyrosine, urea, uric acid or L-valine as sole carbon and nitrogen sources, grew at $37^{\circ} \mathrm{C}$ or in the presence of $10 \%(\mathrm{w} / \mathrm{v}) \mathrm{NaCl}$ or produced alkaline phosphatase, $N$-acetyl- $\beta$-glucosaminidase, $\alpha$-fucosidase, $\beta$-glucuronidase, lipase (C14) or $\alpha$-mannosidase.

\begin{tabular}{|c|c|c|c|c|}
\hline Characteristic & 1 & 2 & 3 & 4 \\
\hline \multicolumn{5}{|l|}{ Acid production from: } \\
\hline Dextrin & - & + & + & - \\
\hline Galactose & - & + & + & + \\
\hline Lactose & - & + & + & - \\
\hline Mannose & + & - & + & + \\
\hline Raffinose & - & + & + & - \\
\hline Salicin & + & + & + & - \\
\hline Sucrose & + & - & + & + \\
\hline Trehalose & + & + & + & - \\
\hline Xylose & - & + & + & + \\
\hline \multicolumn{5}{|l|}{ API ZYM tests } \\
\hline Acid phosphatase & - & + & - & + \\
\hline$\alpha$-Chymotrypsin & - & - & + & + \\
\hline Cystine arylamidase & - & - & + & + \\
\hline$\alpha$-Galactosidase & - & + & - & + \\
\hline$\beta$-Galactosidase & - & + & + & + \\
\hline$\alpha$-Glucosidase & + & - & + & + \\
\hline$\beta$-Glucosidase & + & - & + & + \\
\hline Leucine arylamidase & + & - & + & + \\
\hline Trypsin & - & - & + & + \\
\hline Valine arylamidase & - & - & + & + \\
\hline
\end{tabular}

Table 2. cont.

\begin{tabular}{|lcccc|}
\hline Characteristic & $\mathbf{1}$ & $\mathbf{2}$ & $\mathbf{3}$ & $\mathbf{4}$ \\
\hline Degradation of: & & & & \\
$\quad$ Casein & - & + & - & - \\
DNA & + & - & - & - \\
Tween 60 & - & - & + & + \\
Growth in the presence of $5 \%(\mathrm{w} / \mathrm{v}) \mathrm{NaCl}$ & + & - & + & + \\
Growth at pH 10.0 & + & - & + & + \\
Hydrolysis of urea & + & - & + & + \\
Reduction of nitrate & - & + & + & - \\
Utilization of sole carbon and nitrogen sources & & & & \\
$\quad$ & + & - & - & - \\
L-Asparagine & - & - & + & + \\
L-Histidine & & & & \\
\hline
\end{tabular}

The colonial and cellular morphology of the four representative isolates was examined, as was their ability to grow on PY agar (Tsukamoto et al., 2001) over ranges of temperature and $\mathrm{pH}$. Cellular morphology was examined by electron microscopy following growth on PY agar for 2 days at $30{ }^{\circ} \mathrm{C}$ and negative staining with phosphotungstic acid, as described by Tsukamoto et al. (2001). Cells were Grampositive, non-sporulating, non-motile rods that grew well under aerobic conditions. They formed smooth, circular, convex colonies on brain heart infusion agar (Difco). Growth was observed between 20 and $30^{\circ} \mathrm{C}$, but not at $37^{\circ} \mathrm{C}$, and from $\mathrm{pH} 7.0$ to 10 , but not at $\mathrm{pH} 12$. All of these properties are consistent with the assignment of the strains to the genus Mycetocola (Tsukamoto et al., 2001).

The four representative isolates and the type strains of the three recognized Mycetocola species were examined for a range of biochemical and physiological properties as outlined by Kim et al. (1998). In addition, API ZYM tests (bioMérieux) were performed following the manufacturer's instructions. It is clear from the data in Table 2 that the new isolates share many phenotypic properties, some of which allow them to be distinguished from the Mycetocola type strains.

It can be concluded from the genotypic and phenotypic data presented that the Reblochon cheese isolates represent a novel species of the genus Mycetocola, for which the name Mycetocola reblochoni sp. nov. is proposed.

\section{Description of Mycetocola reblochoni sp. nov.}

Mycetocola reblochoni (re.blo.cho'ni. N.L. neut. n. reblochonum Reblochon cheese; N.L. gen. n. reblochoni of a Reblochon cheese, to denote that the first strains were isolated from the surface of Reblochon cheese).

Aerobic, Gram-positive, asporogenous, non-motile, catalase-positive, rod-shaped actinomycetes $(0.3 \times 1.1-1.5 \mu \mathrm{m})$ that form circular, convex, smooth, shiny colonies on PY agar. Growth occurs between 20 and $30{ }^{\circ} \mathrm{C}$, but not at $37^{\circ} \mathrm{C}$, and between $\mathrm{pH} 7.0$ and $\mathrm{pH} 10$, but not at $\mathrm{pH} 12.0$. Does not hydrolyse allantoin. Additional phenotypic properties are given in Table 2. The organism has 
chemotaxonomic properties consistent with its classification in the genus Mycetocola and forms a distinct phyletic line in the Mycetocola 16S rRNA gene tree. The $\mathrm{G}+\mathrm{C}$ content of the DNA of the type strain is $70.0 \mathrm{~mol} \%$.

The type strain, LMG $22367^{\mathrm{T}}\left(=\mathrm{R}-20377^{\mathrm{T}}=\mathrm{BRB}-1 \mathrm{~L} 41^{\mathrm{T}}\right.$ $=\mathrm{DSM} 18580^{\mathrm{T}}$ ), was isolated from the surface of Reblochon cheese at the late stage of ripening. Reference strains LMG 23020 (=BRB-4LJ1 = R-20402), LMG 23021 $(=\mathrm{BRB}-4 \mathrm{LB} 3=\mathrm{R}-203813)$ and LMG $23022(=\mathrm{BRB}-3 \mathrm{LJ} 5$ $=\mathrm{R}-203891)$ were isolated from the same source.

\section{Acknowledgements}

The study was carried out with financial support from the European Union [project QLK-CT-2001-02228: Biodiversity and anti-listerial activity of surface microbial consortia from Limburger, Reblochon, Livarot, Tilsit and Gubbeen cheese. Acronym SCM (Smear cheese microflora)]. We are indebted to Bruno Mathieu (Syndicat Interprofessionnel du Reblochon) for helpful discussions, to Jennifer Gregor (DSMZ) for excellent technical assistance and to Jean Euzéby (Ecole Nationale Vétérinaire, France) for help with naming the new species.

\section{References}

Brennan, N. M., Brown, R., Goodfellow, M., Ward, A. C., Beresford, T. P., Simpson, P. J., Fox, P. F. \& Cogan, T. M. (2001a). Corynebacterium mooreparkense sp. nov. and Corynebacterium casei sp. nov., isolated from the surface of a smear-ripened cheese. Int J Syst Evol Microbiol 51, 843-852.

Brennan, N. M., Brown, R., Goodfellow, M., Ward, A. C., Beresford, T. P., Vancanneyt, M., Cogan, T. M. \& Fox, P. F. (2001b). Microbacterium gubbeenense sp. nov., from the surface of a smear-ripened cheese. Int J Syst Evol Microbiol 51, 1969-1976.

Brennan, N. M., Ward, A. C., Beresford, T. P., Fox, P. F., Goodfellow, M. \& Cogan, T. M. (2002). Biodiversity of the bacterial flora on the surface of a smear cheese. Appl Environ Microbiol 68, 820-830.

Eliskases-Lechner, F. \& Ginzinger, W. (1995). The bacterial flora of surface-ripened cheeses with special regard to coryneforms. Lait 75, 571-584.

Evtushenko, L. I. \& Takeuchi, M. (2006). The family Microbacteriaceae. In The Prokaryotes: a Handbook on the Biology of Bacteria, 3rd edn, vol. 3, pp. 1020-1098. Edited by M. Dworkin, S. Falkow, E. Rosenberg, K. H. Schleifer \& E. Stackebrandt. New York: Springer.

Evtushenko, L. I., Dorofeeva, L. V., Krausova, V. I., Gavrish, E. Y., Yashina, S. G. \& Takeuchi, M. (2002). Okibacterium fritillariae gen. nov., sp. nov., a novel genus of the family Microbacteriaceae. Int J Syst Evol Microbiol 52, 987-993.

Ezaki, T., Hashimoto, Y. \& Yabuuchi, E. (1989). Fluorometric deoxyribonucleic acid-deoxyribonucleic acid hybridization in microdilution wells as an alternative to membrane filter hybridization in which radioisotopes are used to determine genetic relatedness among bacterial strains. Int J Syst Bacteriol 39, 224-229.

Felsenstein, J. (1985). Confidence limits on phylogenies: an approach using the bootstrap. Evolution 39, 783-791.

Felsenstein, J. (1993). PHYLIP (phylogeny inference package), version 3.5c. Distributed by the author. Department of Genome Sciences, University of Washington, Seattle, USA.

Fitch, W. M. \& Margoliash, E. (1967). Construction of phylogenetic trees: a method based on mutation distances as estimated from cytochrome $c$ sequences is of general applicability. Science 155, 279-284.
Gevers, D., Huys, G. \& Swings, J. (2001). Applicability of rep-PCR fingerprinting for identification of Lactobacillus species. FEMS Microbiol Lett 205, 31-36.

Goris, J., Suzuki, K., De Vos, P., Nakase, T. \& Kersters, K. (1998). Evaluation of a microplate DNA-DNA hybridization method compared with the initial renaturation method. Can J Microbiol 44, 1148-1153.

Groth, I., Schumann, P., Weiss, N., Martin, K. \& Rainey, F. A. (1996). Agrococcus jenensis gen. nov., sp. nov., a new genus of actinomycetes with diaminobutyric acid in the cell wall. Int J Syst Bacteriol 46, 234-239.

Irlinger, F., Bimet, F., Delettre, J., Lefevre, M. \& Grimont, P. A. D. (2005). Arthrobacter bergerei sp. nov. and Arthrobacter arilaitensis sp. nov., novel coryneform species isolated from the surfaces of cheeses. Int J Syst Evol Microbiol 55, 457-462.

Jukes, T. H. \& Cantor, C. R. (1969). Evolution of protein molecules. In Mammalian Protein Metabolism, vol. 3, pp. 21-132. Edited by H. N. Munro. New York: Academic Press.

Kämpfer, P., Rainey, F. A., Andersson, M. A., Nurmiaho Lassila, E. L., Ulrych, U., Busse, H.-J., Weiss, N., Mikkola, R. \& Salkinoja-Salonen, M. (2000). Frigoribacterium faeni gen. nov., sp. nov., a novel psychrophilic genus of the family Microbacteriaceae. Int J Syst Evol Microbiol 50, 355-363.

Kim, S. B., Falconer, C., Williams, E. \& Goodfellow, M. (1998). Streptomyces thermocarboxydovorans sp. nov. and Streptomyces thermocarboxydus sp. nov., two moderately thermophilic carboxydotrophic species from soil. Int J Syst Bacteriol 48, 59-68.

Klatte, S., Rainey, F. A. \& Kroppenstedt, R. M. (1994). Transfer of Rhodococcus aichiensis Tsukamura 1982 and Nocardia amarae Lechevalier and Lechevalier 1974 to the genus Gordona as Gordona aichiensis comb. nov. and Gordona amarae comb. nov. Int J Syst Bacteriol 44, 769-773.

Kluge, A. G. \& Farris, F. S. (1969). Quantitative phyletics and the evolution of anurans. Syst Zool 18, 1-32.

Kroppenstedt, R. M. (1985). Fatty acid and menaquinone analysis of actinomycetes and related organisms. In Chemical Methods in Bacterial Systematics (Society for Applied Bacteriology Technical Series vol. 20), pp. 173-199. Edited by M. Goodfellow \& D. E. Minnikin. New York: Academic Press.

Lee, S. D. (2007). Labedella givakjiensis gen. nov., sp. nov., a novel actinomycete of the family Microbacteriaceae. Int J Syst Evol Microbiol 57, 2498-2502.

MacKenzie, S. L. (1987). Gas chromatographic analysis of amino acids as the $N$-heptafluorobutyryl isobutyl esters. J Assoc Off Anal Chem 70, 151-160.

Manaia, C. M., Nogales, B., Weiss, N. \& Nunes, O. C. (2004). Glucosibacter molinativorax gen. nov., sp. nov., a molinate-degrading bacterium and classification of Brevibacterium helvolum DSM 20419 as Pseudoclavibacter helvolus gen. nov., sp. nov. Int J Syst Evol Microbiol 54, 783-789.

Mesbah, M., Premachandran, U. \& Whitman, W. B. (1989). Precise measurement of the $\mathrm{G}+\mathrm{C}$ content of deoxyribonucleic acid by highperformance liquid chromatography. Int J Syst Bacteriol 39, 159-167.

Minnikin, D. E., O’Donnell, A. G., Goodfellow, M., Alderson, G., Athalye, M., Schaal, A. \& Parlett, J. H. (1984). An integrated procedure for the extraction of bacterial isoprenoid quinones and polar lipids. J Microbiol Methods 2, 233-241.

Park, Y.-H., Suzuki, K., Yim, D.-G., Lee, K.-C., Kim, E., Yoon, J., Kim, S., Kho, Y.-H., Goodfellow, M. \& Komagata, K. (1993). Suprageneric classification of peptidoglycan group B actinomycetes by nucleotide sequencing of 5 S ribosomal RNA. Antonie van Leeuwenhoek 64, 307-313.

Pitcher, D. G., Saunders, N. A. \& Owen, R. J. (1989). Rapid extraction of bacterial genomic DNA with guanidium thiocyanate. Lett Appl Microbiol 8, 151-156. 
Pot, B., Vandamme, P. \& Kersters, K. (1994). Analysis of electrophoretic whole-organism protein fingerprints. In Chemical Methods in Prokaryotic Systematics, pp. 493-521. Edited by M. Goodfellow \& A. G. O'Donnell. Chichester: Wiley.

Saitou, N. \& Nei, M. (1987). The neighbor-joining method: a new method for reconstructing phylogenetic trees. Mol Biol Evol 4, 406-425.

Sambrook, J. \& Russell, D. W. (2001). Molecular Cloning: a Laboratory Manual, 3rd edn. Cold Spring Harbor, NY: Cold Spring Harbor Laboratory Press.

Schleifer, K. H. (1985). Analysis of the chemical composition and primary structure of murein. Methods Microbiol 18, 123-156.

Sheridan, P. P., Loveland-Curtze, J., Miteva, V. I. \& Brenchley, J. E. (2003). Rhodoglobus vestalii gen. nov., sp. nov., a novel psychrophilic organism isolated from an Antarctic Dry Valley lake. Int J Syst Evol Microbiol 53, 985-994.

Stackebrandt, E., Rainey, F. A. \& Ward-Rainey, N. L. (1997). Proposal for a new hierarchic classification system, Actinobacteria classis nov. Int J Syst Bacteriol 47, 479-491.

Takeuchi, M. \& Hatano, K. (1998). Union of the genera Microbacterium Orla-Jensen and Aureobacterium Collins et al. in a redefined genus Microbacterium. Int J Syst Bacteriol 48, 739-747.
Tiago, I., Pires, C., Mendes, V., Morais, P. V., Da Costa, M. \& Veríssimo, A. (2005). Microcella putealis gen. nov., sp. nov., a Grampositive alkaliphilic bacterium isolated from a nonsaline alkaline groundwater. Syst Appl Microbiol 28, 479-487.

Tsukamoto, T., Takeuchi, M., Shida, O., Murata, H. \& Shirata, A. (2001). Proposal of Mycetocola gen. nov. in the family Microbacteriaceae and three new species, Mycetocola saprophilus sp. nov., Mycetocola tolaasinivorans sp. nov. and Mycetocola lacteus sp. nov., isolated from cultivated mushroom, Pleurotus ostreatus. Int J Syst Evol Microbiol 51, 937-944.

Uchida, K., Kudo, T., Suzuki, K. \& Nakase, T. (1999). A new rapid method of glycolate test by diethyl ether extraction, which is applicable to a small amount of bacterial cells of less than one milligram. J Gen Appl Microbiol 45, 49-56.

Valdes-Stauber, N., Scherer, S. \& Seiler, H. (1997). Identification of yeasts and coryneform bacteria from the surface microflora of brick cheeses. Int J Food Microbiol 34, 115-129.

Versalovic, J., Schneider, M., de Bruijn, F. J. \& Lupski, J. R. (1994). Genomic fingerprinting of bacteria using repetitive sequence-based polymerase chain reaction. Methods Mol Cell Biol 5, 25-40.

Zhang, L., Xu, Z. \& Patel, B. K. C. (2007). Frondicola australicus gen. nov., sp. nov., isolated from decaying leaf litter from a pine forest. Int J Syst Evol Microbiol 57, 1177-1182. 